\title{
The Language Acquisition of a Child with Mental Retardation (A Psycholinguistic Study)
}

\author{
Octaria Putri Nurharyani*, Bivit Anggoro Prasetyo Nugroho \\ Fakultas Ilmu Budaya, Universitas Jenderal Soedirman, Indonesia \\ *octaria.putri.nurharyani@unsoed.ac.id, bivit.nugroho@unsoed.ac.id
}

DOI: $10.20884 / 1 . j 1$ li.2020.11.2.2452

\begin{abstract}
Article History:
First Received:

ABSTRACT

$12 / 03 / 2020$

Final Revision:

This research aims at describing the language acquisition or the ability to acquire language of a child with mental retardation. The data of this study is the language acquisition of a 2-year-old-child with mental $18 / 11 / 2020$ retardation. Data sources were categorized into two groups; the primary data was obtained from the child, and the secondary data was Available online: from literature sources (books about psycholinguistics). This research

$29 / 12 / 2020$ used descriptive qualitative method. Data were collected, clarified, and analyzed according to the established stages, namely cognitive stage, mother language acquisition stage, and linguistik acquisition stage. The result of the study indicated that there was a delay in the language acquisition of the child with mental retardation, yet the process was in a good development.
\end{abstract}

\section{Keywords: language acquisition; mental retardation; psycholinguistics}

\section{PENDAHULUAN}

Manusia memiliki kemampuan lahiriah untuk berbahasa, hal ini ditunjukkan melalui mudahnya manusia untuk mempelajari bahasa, baik dalam proses pemerolehan bahasa maupun dalam proses pembelajaran bahasa. Proses pemerolehan bahasa terjadi sejak masa kanak-kanak, bahkan sejak lahir manusia sudah diperkenalkan dengan bahasa, melalui adanya stimulus kebahasaan yang diberikan oleh orang tua dan orang-orang disekitarnya, sedangkan proses pembelajaran bahasa terjadi setelah pemerolehan bahasa dikuasai yakni bahasa ibu, kemudian dikembangkan melalui proses pembelajaran bahasa.

Proses pemerolehan bahasa berkaitan pula dengan stimulus kebahasaan. Stimulus kebahasaan merupakan kegiatan penggunaan bahasa yang dilakukan oleh seseorang atau masyarakat yang bertujuan memberikan rangsangan kebahasaan untuk menunjang proses pemerolehan bahasa atau akuisisi bahasa. Melalui adanya stimulus bahasa yang diberikan secara 
terus menerus dan berkelanjutan, akan menunjang kemampuan seseorang terutama pada tahap kanak-kanak dalam memperoleh bahasa terutama bahasa ibunya.

Akuisisi atau pemerolehan bahasa sendiri merupakan proses berlangsungnya pemerolehan bahasa pertama atau bahasa ibu seorang kanak-kanak yang berlangsung di dalam otak (Chaer, 2009). Pada tahap pemerolehan bahasa atau akuisisi, memiliki dua proses yang terjadi di dalamnya, yakni proses kompetensi dan proses performansi. Proses kompetensi adalah proses penguasaan tata bahasa yang berlangsung secara alami atau tanpa disadari, sedangkan pada proses performansi merupakan tahap aplikasi dari proses kompetensi. Pada tahap performansi memiliki dua proses di dalamnya, yakni proses pemahaman dan proses penerbitan atau proses menghasilkan kalimat-kalimat. Proses pemahaman melibatkan kemampuan mencermati atau kepandaian mengamati dan mempersepsi ujaran yang berupa kalimat-kalimat yang didengar. Proses penerbitan merupakan kemampuan yang dimiliki seseorang dalam mengeluarkan, menghasilkan, atau menerbitkan kalimat-kalimat sendiri.

Tahap kompetensi dan performansi terjadi pada masa kanak-kanak. Setiap anak memiliki kemampuan yang berbeda-beda pada tahap pemerolehan bahasanya. Hal ini berkaitan dengan kemampuan kognitif anak dalam memperoleh bahasanya, terutama bahasa ibu. Indah (2017) menyampaikan bahwa, setiap anak yang normal pertumbuhan pikirannya, akan memperoleh bahasa pertama atau bahasa ibu dalam tahun-tahun pertama hidupnya, dan proses ini terjadi hingga anak-anak berusia 5 tahun. Anak-anak tetap memperoleh bahasa ibu pada masa pubertas (sekitar usia 12-14 tahun) hingga menginjak dewasa (sekitar 18-20 tahun). Sesudah pubertas, kemampuan bahasa anak sudah semakin matang dan baik, namun masih harus terus dikembangkan disamping pembelajaran bahasa yang lain.

Pemerolehan bahasa ibu merupakan bahasa yang utama bagi anak karena bahasa ibu adalah bahasa yang pertama kali didengar dan dipelajari oleh anak, sehingga apabila bahasa ini digunakan secara terus menerus dan berulang, maka kemampuan berbahasa pada anak mengenai bahasa ibunya akan semakin berkembang dan matang.

Menurut Dardjowijojo (2008) dalam pemerolehan bahasa, teori yang paling mendasar adalah teori hipotesis nurani (Innateness hypothesis) yang menyebutkan bahwa Language Acquisition Device (LAD) atau Piranti Pemerolehan Bahasa (PPB) sangat berpengaruh terhadap pemerolehan bahasa terutama bahasa ibu. Menurut Chomsky dalam Chaer (2009) dan Dardjowidjodjo (2008), sebagai pelopor pandangan nativisme, LAD dimiliki setiap manusia, bahkan sejak anak lahir, sehingga memungkinkan anak memperoleh bahasa, baik bahasa ibu maupun bahasa lainnya. Disamping itu, LAD mampu mendasari kemampuan anak untuk memperkirakan secara alami struktur bahasa yang akan diperoleh. Oleh karena itu, banyak ciri-ciri tata bahasa ibu yang tidak 
perlu dipelajari seseorang secara khusus atau melalui program. Hal ini diasumsikan bahwa polapola dan struktur-struktur bahasa yang dibawa sejak lahir sama dalam semua bahasa. Penjelasan tersebut, dapat dikategorikan ke dalam struktur harfiah (deep structure) dalam tata bahasa semesta (gramatika universal) (Indah, 2017).

Melalui LAD yang dimiliki, akan mempermudah manusia dalam menghafal, menirukan, dan menguasai struktur bahasa yang bersifat rumit, kompleks, dan bersifat universal. LAD dapat berjalan dengan baik apabila ada perangkat pendukung yang mendampingi, yakni harus didukung dengan adanya stimulus respon yang diberikan oleh lingkungan sekitar, terutama peran dari orang tua yang harus selalu memberikan stimulus untuk dapat melihat respon yang ditunjukkan oleh anak dalam pemerolehan bahasanya.

Proses pemerolehan bahasa itu sendiri berkaitan dengan kemampuan otak kanak-kanak ketika memperoleh bahasa pertamanya atau bahasa ibu. Pemerolehan bahasa kanak-kanak bersifat internal yang mencakup tingkah laku dan komunikasi verbal. Pemerolehan bahasa pada kanakkanak berkaitan juga dengan tumbuh kembang dan tingkat kemampuan dari masing-masing anak.

Masalah tumbuh kembang anak merupakan masalah yang penting untuk diperhatikan. Hal ini dikarenakan, perkembangan berkaitan atau berhubungan dengan bertambahnya kemampuan dalam struktur dan fungsi tubuh baik yang berhubungan dengan kemampuan motorik maupun kognitif. Hal ini juga disampaikan Soetjaningsih (2014) yang menyatakan bahwa tumbuh kembang merupakan perwujudan yang kompleks dari perubahan morfologi, biokimia, dan fisiologi yang terjadi pada masa kanak-kanak hingga dewasa. Tumbuh kembang secara harfiah merupakan dua peristiwa yang berbeda tetapi saling berkaitan dan sulit dipiisahkan. Tumbuh (pertumbuhan) merupakan perubahan yang bersifat kuantitafif artinya mencakup bertambahnya jumlah, ukuran, dimensi pada tingkat sel, organ maupun individu. Hal ini dicirikan melaluli pertumbuhan secara fisik yaitu tubuh, serta pertumbuhan pada organ-organ tubuh dan otak. Otak yang mengalami pertumbuhan sempurna akan memiliki kapasitas lebih besar untuk belajar, mengingat, dan mempergunakan akalnya. Sedangkan kembang (perkembaangan) berkaitan dengan perubahan yang bersifat kuantitatif dan kualitatif, yaitu ditandai dengan bertambahnya kemampuan (skill) dan fungsi tubuh yang semakin kompleks, dengan ritme yang dapat diramalkan serta pola yang teratur. Hal ini terjadi sebagai hasil dari proses pematangan diri. Perkembangan juga menyangkut proses diferensiasi atau proses pembedaan dari bagian-bagian dari komponen tubuh manusia yaitu sel-sel tubuh, jaringan tubuh, organ-organ dan sistem organ yang berkembang sehingga masing-masing dapat memenuhi fungsinya. Perkembangan berkaitan pula dengan perkembangan kognitif, motorik, bahasa, emosi, dan perkembangan perilaku sebagai hasil dari interaksi dengan 
lingkungan. Tumbuh kembang seperti ini, dapat dilihat pada anak-anak yang mengalami pertumbuhan dan perkembangan dengan baik dari kanak-kanak hingga dewasa termasuk bagaimana kemampuan pemerolehan bahasa dan perkembangan bahasanya.

Berkaitan dengan hal di atas, kemampuan berbahasa yang dimulai melalui proses pemerolehan bahasa, merupakan indikator seluruh perkembangan anak, karena kemampuan berbahasa berpengaruh dan mempengaruhi serta berkaitan dengan keterlambatan atau kelainan pada sistem lainnya seperti kemampuan kognitif, sensorimotor, psikologis, emosi, dan lingkungan di sekitar anak (Soetjaningsih, 2014). Anak-anak yang lahir normal dan mengalami tumbuh kembang yang baik, kemampuan pemerolehan bahasanya lebih sempurna dari pada anak-anak yang lahir dalam kondisi tidak normal atau mengalami gangguan pertumbuhan, salah satunya adalah anak yang mengalami gangguan retardasi mental atau Mental Retardation. Retardasi mental menurut Pedoman Penggolongan dan Diagnosis Gangguan Jiwa (PPDGJ) dalam Ramayumi, Nurdin, \& Nurhajjah (2014) merupakan suatu keadaan perkembangan jiwa yang terhenti atau tidak lengkap, yang terutama ditandai oleh terjadinya kendala keterampilan selama perkembangan. Menurut Charter CH dalam Soetjaningsih (2014), retardasi mental adalah suatu kondisi yang ditandai kemampuan intelegensi di bawah rata-rata sehingga menyebabkan ketidakmampuan individu untuk belajar. Penderita Retardasi mental memiliki kemampuan mental atau intelegensi di bawah rata-rata ( $\mathrm{IQ}<70-75)$, yang mengakibatkan keterbatasan pada keterampilan adaptif, yaitu keterampilan dalam berkomunikasi, menolong diri sendiri, home living, keterampilan sosial, bermasyarakat, kesehatan, fungsi akademik, menggunakan waktu luang.

Penetapan IQ penderita retardasi mental memiliki kriteria berbeda, salah satunya berdasarkan American Assoication Mental Deficiency (AAMD) dan menurut World Health Organization (WHO). Menurut AAMD dan WHO dalam Soetjaningsih (2014) subkalsifikasi retardasi mental dibagi menjadi 4 yaitu retardasi mental ringan, sedang, berat, dan sangat berat.

Tabel 1. Retardasi Mental

\begin{tabular}{lcc}
\hline Derajat & $\begin{array}{c}\text { American Association } \\
\text { Mental Deficiency }\end{array}$ & $\begin{array}{c}\text { Word Health } \\
\text { Organization }\end{array}$ \\
\hline Ringan & $55-69$ & $50-70$ \\
Sedang & $40-54$ & $35-49$ \\
Berat & $25-39$ & $20-34$ \\
Sangat Berat & $0-24$ & $0-20$ \\
\hline
\end{tabular}


AAMD menyampaikan bahwa IQ penderita retardasi mental berada pada kisaran 55, sedangkan menurut WHO berada pada angka 50, hal ini menunjukan bahwa IQ anak-anak penderita retardasi mental memang di bawah rata-rata. Keterbatasan IQ anak dengan retardasi mental mengakibatkan anak tidak dapat mengikuti pendidikan sekolah biasa, hal ini disebabkan karena anak retardasi mental memiliki cara berpikir yang terlalu sederhana, daya tangkap dan daya ingat terlalu lemah, serta kemampuan berbahasa dan berhitungnya juga lemah. Oleh karena itu, anak dengan retardasi mental harus diberikan pendampingan khusus dalam proses, melatih kemampuan diri, termasuk kemampuan pemerolehan bahasanya.

Retardasi mental dapat disebabkan oleh beberapa faktor diantaranya karena aspek biologis yang mencakup gangguan kromosom dan genetis, penyakit infeksi dan penggunaan alkohol pada saat ibu hamil. Penyebab retardasi mental juga bersifat multifaktoral, artinya banyak faktor yang berperan dalam terjadinya retardasi mental ini, dan semua saling mempengaruhi (Ramayumi, Nurdin, \& Nurhajjah, 2014). Salah satu gangguan kemampuan yang muncul pada retardasi mental adalah gangguan pada sistem saraf.

Penelitian mengenai retardasi mental sudah pernah dilakukan oleh Pratiwi, Handayani, \& Raharjo (2017) yang meneliti mengenai kemampuan kognitif anak retardasi mental berdasarkan status gizi, sedangkan penelitian yang dilakukan Martina, Syam, \& Saman (2014) meneliti mengenai aktivitas berbahasa anak berkebutuhan khusus pada lembaga pendidikan dan pelatihan. Selanjutnya, penelitian yang dilakukan Ramayumi, Nurdin, \& Nurhajjah (2014) meneliti mengenai karakteristik penderita retardasi mental di SLB Kota Bukittinggi. Beberapa penelitian tersebut membahas mengenai anak retardasi mental terkait dengan kemampuan kognitif, kemampuan berbahasa, serta ciri-ciri dari penderita retardasi mental, tetapi tidak terfokus pada pemerolehan bahasa ibu dan tahap pemerolehan bahasa secara linguistiknya.

Pemerolehan bahasa berkaitan sistem yang dimiliki manusia dan kemampuan kognitif otak. Setiap kanak-kanak secara lahiriah sudah dikaruniai kemampuan untuk berbahasa yang Chomsky sebut sebagai Language Acquisition Device (LAD). Anak penderita retardasi mental memiliki LAD yang dimiliki sejak lahir dan berfungsi untuk memungkinkan anak-anak memperoleh bahasanya. Menurut Chomsky dalam Chaer (2009) dan Dardjowidjodjo (2008), LAD merupakan sistem yang dimiliki setiap kanak-kanak untuk mempelajari bahasa, baik pada anak yang normal maupun yang memiliki keterbatasan. LAD bekerja karena adanya stimulus yang diberikan dan hasilnya berupa respon. Hal ini dapat dilakukan melalui proses komunikasi yang dilakukan oleh orang tua dan lingkungan yang dilakukan secara terus menerus. 
Pemerolehan bahasa tentunya berhubungan dengan kemampuan sistem saraf, hal ini berkaitan dengan kemampuan unik manusia untuk memperoleh bahasa yaitu hasil dari keberfungsian sistem saraf. Ketidaksempurnaan pada sistem saraf akan mempengaruhi kemampuan berbahasa seseorang. Gangguan ini sangat kompleks menyangkut bidang kognitif, komunikasi, interaksi sosial, ketetarikan, dan aktivitas imajinasi anak, serta emosi anak (Endarwati, 2015). Hal inilah yang menjadi salah satu penyebab munculnya kendala pemerolehan bahasa pada anak penderita retardasi mental. Kemampuan kognitif berpengaruh dalam proses berkomunikasi, terutama dalam proses pemerolehan bahasa. Anak retardasi mental tentunya memiliki kemampuan yang berbeda dalam hal pemerolehan bahasanya oleh karena itu perlu ada penelitian mengenai pemerolehan bahasa yang dihasilkan anak retardasi mental.

Penelitian mengenai pemerolehan bahasa pada anak berkebutuhan khusus, sudah pernah dilakukan tahun 2018 oleh Pandudinata, Sumarlam, \& Saddhono. Mereka meneliti mengenai pemerolehan bahasa pada siswa tunagrahita kelas VI SD. Selain itu, ditemukan penelitian yang dilakukan oleh Putri (2018) yang membahas mengenai kemampuan berbahasa pada anak lahir prematur.

Dua penelitian tersebut, memiliki objek kajian dan analisis yang berbeda dengan objek kajian penulis yakni penderita retardasi mental. Tunagrahita cenderung seperti kepada penderita down sindrome, sedangkan anak lahir prematur adalah kondisi anak yang memiliki permasalahan dengan kemampuan perkembangan otak dan kemampuan perkembangan emosi yang disebabkan karena bayi lahir belum waktunya atau disebut bayi prematur. Beberapa resiko yang muncul terhadap tumbuh kembang bayi prematur, yaitu: gangguan pendengaran dan penglihatan, gangguan kemampuan bahasa, psikomotorik dan perilaku, gangguan kemampuan kognitif, dan gangguan perkembangan emosional.

Retardasi mental salah satu penyebabnya adalah gangguan pada masa kehamilan yang mempengaruhi pertumbuhan janin sehingga mempengaruhi fungsi otak, seperti dalam objek penelitian penulis, yakni anak penderita retardasi mental yang disebabkan karena gangguan pada masa kehamilan berupa kelainan kromosom yang sebelumnya ibu dari anak penderita retardasi mental pernah terkena virus toksoplasma. Pada penelitian Tunagrahita dan Bayi lahir prematur, membahas mengenai pemerolehan bahasa tanpa menginformasikan tahapan-tahapan yang dilalui, sedangkan dalam penelitian ini membahas pemerolehan bahasa dengan mendeskripsikan tahapantahapan bahasa yang dilalui. Berdasarkan pernyataan tersebut, kajian ini dibuat untuk mengetahui bagaimanakah pemerolehan bahasa pada anak penderita retardasi mental yang telah berusia dua tahun dengan pendekatan ilmu Psikolinguistik dilihat melalui proses tahapan-tahapannya. 
Pemerolehan bahasa merupakan salah satu bagian dari kegiatan berbahasa. Kegiatan berbahasa tidak hanya berlangsung secara mekanistik, tetapi juga berlangsung secara mentalistik. Artinya, kegiatan berbahasa itu berkaitan dengan proses atau kegiatan mental (otak) (Chaer, 2009). Oleh karena itu, pembahasan tentang penelitian ini menggunakan kajian Psikolinguistk. Psikolinguistik sendiri adalah ilmu yang mempelajari proses-proses mental yang dilalui oleh manusia dalam mereka berbahasa (Dardjowidjojo, 2008).

Dalam perkembangannya, Psikolinguistik tidak lagi berdiri sebagai ilmu yang terpisah dari ilmu-ilmu lain karena pemerolehan dan penggunaan bahasa manusia menyangkut banyak cabang ilmu pengetahuan yang lain. Psikolinguistik sendiri tidak hanya berkaitan dengan psikologi dan linguistik tetapi juga berkaitan dengan ilmu-ilmu lain seperti neurologi, filsafat, primatologi, dan genetika. Berkaitan dengan hal tersebut, dalam ilmu kedokteran (Soetjaningsih, 2014) pada tahap tumbuh kembang keterampilan berbahasa anak dengan retardasi mental memiliki beberapa tahap dan tahapan ini juga dapat diketahui dan dibuktikan melalui tahapan pemerolehan bahasa secara linguistik.

Tabel 2. Tahapan Pemerolehan Bahasa Secara Linguistik

\begin{tabular}{|c|c|c|c|}
\hline $\begin{array}{c}\text { Umur } \\
\text { Pemerolehan }\end{array}$ & Keterampilan Bahasa & $\begin{array}{c}\text { Umur } \\
\text { Dikatakan } \\
\text { Terlambat }\end{array}$ & $\begin{array}{c}\text { Temuan Abnormal atau Red } \\
\text { Flag yang Perlu Dilakukan } \\
\text { Assesment }\end{array}$ \\
\hline Baru lahir & $\begin{array}{l}\text { a. Respon terhadap suara } \\
\text { b. Ketertarikan sosial } \\
\text { terhadap wajah dan } \\
\text { orang }\end{array}$ & $\begin{array}{l}\text { Segera } \\
\text { setelah lahir }\end{array}$ & $\begin{array}{l}\text { a. Tidak ada respon terhadap } \\
\text { suara } \\
\text { b. Tidak tertarik untuk } \\
\text { berinteraksi dengan orang }\end{array}$ \\
\hline $2-4$ bulan & $\begin{array}{l}\text { Cooing, menoleh ke } \\
\text { arah pembicara }\end{array}$ & 4 bulan & $\begin{array}{l}\text { Tidak ada respon terhadap setiap } \\
\text { usaha untuk berkomunikasi } \\
\text { setelah umur } 4 \text { bulan }\end{array}$ \\
\hline $4-5$ bulan & $\begin{array}{l}\text { Babbling (mengulang } \\
\text { konsonan/kombinasi } \\
\text { vocal) }\end{array}$ & 9 bulan & $\begin{array}{l}\text { Kehilangan kemampuan untuk } \\
\text { babbling }\end{array}$ \\
\hline 6 bulan & Respon terhadap suara & 9 bulan & $\begin{array}{l}\text { Lokasi terhadap suara lemah } \\
\text { atau tidak responsif }\end{array}$ \\
\hline $9-12$ bulan & $\begin{array}{l}\text { a. Memahami } \\
\text { verbal } \\
\text { b. Menunjuk }\end{array}$ & 15 bulan & $\begin{array}{l}\text { a. Pemahaman yang lemah } \\
\text { terhadap perintah verbal } \\
\text { rutin, seperti da...da } \\
\text { b. Sekali-sekali bisa menunjuk } \\
\text { untuk menyatakan } \\
\text { keinginannya, tetapi tidak }\end{array}$ \\
\hline
\end{tabular}




$\begin{aligned} 10-16 \text { bulan a. } & \text { Memproduksi kata- } 18 \text { bulan } \\ & \text { kata tunggal } \\ \text { b. } & \text { Menunjuk bagian- } \\ & \text { bagian tubuh, atau } \\ & \text { memahami kata-kata } \\ & \text { tunggal }\end{aligned}$
18-24 bulan a. Memahami kalimat 24 bulan sederhana

b. Perbendaharaan kata 30 bulan meningkat pesat

c. Mengucapkan kalimat 30 bulan yang terdiri dari dua kata-kata/lebih bisa menunjuk benda yang menarik perhatiannya

a. Gagal menggunakan katakata, gagal menambah katakata baru, kehilangan katakata yang sebelumnya telah didapat

b. Tidak bisa menunjuk bagian-bagian tubuh, atau tidak bisa mengikuti perintah sederhana

a. Pemahaman minimal dan bermain simbol yang terbatas, misalnya main boneka atau truk

b. Kurang dari 30 kata-kata pada umur 24 bulan atau kurang dari 50 kata-kata pada umur 30 bulan

c. Gagal membuat kalimat yang terdiri dari dua katakata

Psikolinguistik digunakan sebagai dasar penelitian ini dengan tujuan untuk mengetahui kemampuan pemerolehan bahasa pada anak dengan kondisi tidak sempurna baik fisik maupun mentalnya yang terfokus pada penderita retardasi mental khususnya yang berusia dua tahun. Penelitian ini mengambil kasus pada anak usia dua tahun, karena penelitian ini terfokus pada tahap awal pemerolehan bahasa secara linguistik, dan tahapan yang dilalui berada pada anak usia dua tahun. Pemerolehan bahasa pada penelitian ini, akan dilihat dari tahap kemampuan kognitif, tahap pemerolehan bahasa ibu (tahap ocehan (babbling), tahap satu kata (holofrastic), tahap dua kata, dan tahap telegrafis), serta tahap pemerolehan linguistik (pemerolehan fonologi, pemerolehan sintaksis, dan pemerolehan semantik).

\section{METODE}

Metode penelitian yang digunakan dalam penelitian ini adalah metode deskriptif kualitatif. Metode memegang peranan penting dalam suatu penelitian agar tujuan yang diharapkan dapat tercapai. Penelitian ini menggunakan metode pengamatan, observasi, dan wawancara. Penelitian dilakukan selama kurang lebih 2 bulan dengan melakukan pengamatan pada anak penderita retardasi mental berusia 2 tahun. Penelitian dilakukan pada salah seorang anak yang tinggal di daerah desa Kradenan Kabupaten Sukoharjo. Pengamatan dan observasi dilakukan secara 
langsung ketika anak sedang beraktifitas, kemudian saat berinteraksi langsung dengan peneliti dan orang tuanya. Wawancara dilakukan pada anak ketika berinteraksi langsung melalui pertanyaanpertanyaan yang bersifat umum salah satunya menanyakan benda-benda yang berada di sekitarnya untuk mengetahui bagaimana respon dari anak, apakah menunjukkan melalui bahasa atau hanya melalui kemampuan motorik saja. Data lain diperoleh melalui wawancara dengan orang tua dari anak tersebut. Penggunaan metode tersebut bertujuan mengetahui seberapa banyak pemerolehan bahasa yang dihasilkan pada anak penderita retardasi mental yang berusia 2 tahun.

\section{HASIL DAN PEMBAHASAN}

Setiap anak terlahir dengan kecerdasan dan kemampuan mental yang berbeda-beda. Namun, ada sebagian anak yang tingkat kecerdasan dan kemampuan mentalnya di bawah rata-rata. Kondisi inilah yang disebut dengan retardasi mental atau disabilitas intelektual (Ramayumi, Nurdin, \& Nurhajjah, 2014). Retardasi mental dapat terjadi karena ada gangguan atau masalah sejak ibu mengandung. Salah satu gangguan yang menyebabkan anak menderita retardasi mental adalah, ibu hamil pernah terjangkit toksoplasma saat mengandung. Penelitian ini mengkaji pemerolehan bahasa anak penderita retardasi mental yang berusia 2 tahun bernama Herman. Anak tersebut mengalami retardasi mental disebabkan karena adanya gangguan kehamilan pada ibu saat mengandung Herman. Ibu Herman terindikasi terjangkit virus toksoplasma saat kandungan berusia 2 bulan.

Retardasi mental biasanya dapat diketahui atau terdeteksi saat usia anak masih dini, bahkan saat bayi. Hal ini dapat dilihat melalui gejala dan tanda yang ditunjukkan oleh anak, misalnya ketika lahir, bayi memiliki abnormalitas fisik karena kelainan genetik, ketika masa pertumbuhan, mengalami keterlambatan dalam berjalan dan biasanya merangkak, gangguan berbicara yakni keterlambatan dalam berbicara, gangguan perilaku atau tantrum, lamban dalam mempelajari sesuatu misalkan berpakaian, membersihkan diri, dan makan. Selain itu ada beberapa ciri umum lain yang menandakan gejala retardasi mental yakni sering berputar, duduk berdiri, kemudian kesulitan untuk mengingat barang, serta kesulitan untuk berhubungan dan berkomunikasi dengan orang lain. Anak penderita retardasi mental berat biasanya akan disertai pula dengan masalah kesehatan lainnya. Masalah ini terkait kejang, gangguan perasaan seperti cemas dan autimisme, kelainan motorik, serta gangguan penglihatan atau gangguan pendengaran. Pada kasus ini, retardasi mental yang diderita Herman dicirikan seperti hal-hal tersebut di atas, diantaranya keterlambatan berjalan, gangguan perilaku yakni terkadang sering menangis tanpa sebab, lamban 
dalam mempelajari sesuatu, sulit berhubungan dan berkomunikasi dengan orang lain, adanya gangguan pendengaran dan penglihatan.

Kemampuan pemerolehan bahasa pada anak penderita retardasi mental lebih membutuhkan perhatian khusus dibandingkan dengan anak yang lahir dengan kondisi normal. Hal ini dikarenakan, anak penderita retardasi mental memiliki kemampuan fungsi otak yang tidak sempurna, sehingga dalam kemampuan memeperoleh bahasa ibunya, harus lebih sering diberikan stimulus secara terus menerus dan melalui tahap-tahap yang lebih khusus. Bahasa ibu yang digunakan Herman adalah bahasa Jawa standar karena Herman berdomisili di daderah Sukoharjo yang berdekatan dengan kota Surakarta dan Klaten sehingga bahasa Jawa yang digunakan adalah bahasa Jawa standar.

Pemerolehan bahasa anak penderita retardasi mental harus melalui tahapan yang lebih matang dan mapan, dalam hal ini, tidak memaksakan pemerolehan bahasa ibu dengan memfosir tuturan yang diujarkan dengan berlebihan. Maksudnya, tidak memperkenalkan dan mengajarkan kosa kata bahasa ibu terlalu cepat dan terlalu banyak. Apabila hal ini terjadi, akan mempengaruhi mental anak sehingga dapat mempersulit anak penderita retardasi mental dalam memahami dan memaknai ujaran. Pada kasus Herman, orang tua tidak memaksakan Herman harus mampu berbicara bahasa ibu yang diajarkan. Hal ini dibuktikan melalui komunikasi yang digunakan sehari-hari, orang tua lebih banyak mengajarkan dan menginformasikan bahasa ibu melalui tindakan secara langsung, tidak memaksakan Herman untuk mengulang kata-kata yang diucapkan oleh orang tuanya. Tindakan ini bertujuan melatih pemahaman dan tidak terfokus pada penguasaan bahasa. Meskipun demikian, Herman terkadang berusaha mengingat dan mengulang kembali katakata yang telah didengarnya tanpa perintah dari orang tua.

Terkait dengan pembahasan di atas, salah satu kendala yang dihadapi anak penderita retardasi mental dalam pemerolehan bahasa diantaranya meliputi pemahaman kalimat, mengekspresikan diri melalui bahasa, mengolah kata, dan artikulasi (pengucapan). Hal-hal tersebut juga terjadi pada Herman. Herman belum mampu memahami secara maksimal kalimat yang terlalu panjang dan belum mampu mengekspresikan diri melalui bahasa yang diperoleh, namun pemerolehan bahasa yang diperoleh Herman sudah menunjukkan perkembangan yang baik dilihat melalui tahapan-tahapan pemerolehan bahasa yang dilalui.

Tahapan-tahapan pemerolehan bahasa anak penderita retardasi mental pada kasus Herman, diantaranya adalah pemerolehan bahasa dilihat dari tahap kemampuan kognitif, tahap pemerolehan bahasa ibu, dan tahap pemerolehan linguistik. Tahapan-tahapan tersebut akan dijabarkan lebih lanjut pada pembahasan selanjutnya. Tahapan-tahapan yang dilalui anak penderita retardasi mental. 


\section{Tahap Kognitif Anak Penderita Retardasi Mental Usia 2 Tahun}

Kognisi atau kemampuan kognitif berkaitan dengan peristiwa mental yang berhubungan dengan proses pengenalan tentang dunia yang melibatkan pikiran atau berpikir. Tahap kognisi pemerolehan bahasa anak, khususnya perkembangan kognitif tidak terlepas dari pandangan Piaget yang menyatakan bahwa bahasa merupakan salah satu kemampuan yang berasal dari kematangan kognitif. Kematangan kognitif tentunya berkaitan dengan peran neurologi yang sudah dimiliki anak sejak lahir. Hal ini berkaitan dengan otak beserta fungsi-fungsinya. Apabila kemampuan otak pada anak tidak mencukupi maka akan berpengaruh kepada bagaimana kemampuan sensomotor dan pemerolehan bahasanya.

Berkaitan dengan hal di atas, bahasa diperoleh berdasarkan struktur atau komponen sensori motor yang muncul sebelum adanya tahap perkembangan. Struktur atau komponen ini diperoleh anak-anak melalui interaksi dengan benda-benda atau orang-orang di sekitarnya. Tahap sensori motor pada anak penderita retardasi mental dalam hal ini pada kasus Herman, diperoleh melalui interaksi yang terus menerus antara tingkat fungsi kognitif Herman dengan lingkungan kebahasaannya. Hal ini sangat berpengaruh terhadap proses pemerolehan bahasa yang diperoleh dan dihasilkan Herman karena ketika kemampuan sensori motor semakin baik, .

Komponen sensori motor berkaitan dengan kemampuan pemerolehan bahasa pada anak. Seorang anak yang sedang memperoleh bahasa pertama atau bahasa ibunya, mengalami dua proses di dalamnya yaitu proses kompetensi dan proses performansi. Proses kompetensi adalah proses penguasaan tata bahasa yang berlangsung secara alami dan tidak disadari. Proses kompetensi merupakan hal utama yang harus ada sebelum terjadinya proses performansi yang berkaitan dengan proses memahami dan menghasilkan ujaran. Pada Kasus Herman, proses kompetensi sudah dilalui dan masuk dalam tahap pengembangan, hal ini dapat dilihat dari pemerolehan bahasa ibunya, meskipun belum maksimal, tetapi ada beberapa kata yang sudah diperoleh Herman melalui informasi yang didengar dari lingkungan disekitarnya, terutama saat berinteraksi dengan orang tua. Herman berusaha memahami ujaran yang didengar dan dilihatnya. Pada proses ini, melibatkan kemampuan mempersepsi atau menafsirkan pemahaman kalimat yang didengar dan ditunjukkan dari orang-orang disekitarnya. Proses performansi juga sudah dilalui dengan menghasilkan sedikit bunyi-bunyi bahasa ketika merespon stimulus baik pertanyaan maupun pernyataan.

Tahap pemerolehan bahasa pada anak yang berhubungan dengan kemampuan kognitif, diantaranya adalah, antara usia $0-1.5$ tahun, anak-anak belajar mengembangkan pola-pola aksi 
tanpa disadari dengan cara bereaksi terhadap alam sekitar. Melalui proses pengembangan pola inilah yang kemudian diatur menjadi struktur-struktur akal (mental). Setelah struktur aksi dinuranikan, anak mulai memasuki tahap representasi kecerdasan yang terjadi antara usia 2 tahun sampai 7 tahun yakni ditunjukkan melalui sikap mulai memahami alam sekitar baik yang berupa simbol ataupun tindakan. Setelah tahap representasi kecerdasan dan representasi simbolik berakhir, maka bahasa anak-anak semakin berkembang dan struktur-struktur atau komponenkomponen linguistik sudah mulai terbentuk.

Tahap-tahap tersebut dapat dilalui pada anak penderita retardasi mental, yakni Herman, namun mengalami keterlambatan. Meskipun demikian, tahap pemerolehan bahasa pada kasus Herman dapat berjalan meskipun membutuhkan waktu lebih lama dibandingkan kondisi anak pada umumnya. Hal ini tentunya juga berhubungan dengan kemampuan kognitif pada masing-masing anak, terutama anak dalam kondisi yang memiliki keterbatasan. Herman menunjukkan kemampuan sensori motor dengan menunjukkan keingintahuannya terhadap benda-benda yang berada di sekitarnya, misalkan dengan menunjukkan benda tersebut kepada orang tuanya, dengan tujuan menanyakan benda apa itu, apabila benda tersebut belum diketahui Herman.

Tahap kognitif pada Herman yang lain mengalami kemajuan yang cukup baik meskipun belum maksimal, hal ini ditunjukkan melalui ujaran yang dihasilkan berupa kosa kata yang diperoleh Herman ketika berusia antara satu setengah sampai dua tahun, hal tersebut sebagai hasil dari peralihan intelek kepada representasi akal (mental). Pada kasus Herman, usia dua tahun belum dapat mengasilkan kosa kata yang sempurna, tetapi Herman dapat mengucapkan satu suku kata dengan cukup baik. Selanjutnya, dalam memahami dunia sekitar yang awalnya berada pada usia 18 bulan, anak retardasi mental baru dapat memahami melalui indra (sensory) dan gerak kegiatan yang dilakukan (motor) pada umur 2 tahun. Hal ini terjadi pada kondisi Herman, tahap sensorimotor belum terlaksana dengan baik, namun mengalami kemajuan secara berkala dan terus menerus.

Tahap sensorimotor belum mengalami kemajuan dengan baik karena ada faktor lain yang mempengaruhi. Pada kasus Herman, diindikasi mengalami gangguan pendengaran dan penglihatan yang diketahui melalui proses observasi dan konfirmasi ketika percakapan berlangsung, yakni pertanyaan dan komunikasi yang berlangsung harus diulang kembali dan tidak cukup hanya satu kali ujaran saja. Meskipun demikian, perkembangan kemampuan pemerolehan bahasa sudah memiliki kemajuan, hal ini dibuktikan melalui pemahaman yang ditunjukkan Herman, dengan merespon pertanyaan yang disampaikan kepadanya.

Hal tersebut terbukti pada komunikasi antara orang dewasa, yakni peneliti dan anggota keluarga saat berkomunikasi dengan Herman: 
Tante : "Herman, rene, karo bulik".

Herman : ("menggeleng dan menganggukkan kepala, serta berputar, kemudian berjalan, tetapi belum seimbang, menghampiri orang dewasa 1").

Tante : "Herman, nonton opo yo? nonton kartun yo?.

Herman : "(menarikjari bulik, dan mememinta bulik duduk di sampingnya)”.

Tante : "wah nonton opo kuwi, apik yo Man, (sambil mengobrol dengan orang dewasa lainnya)".

Herman : "(memukul-mukulkan tangan ke tubuh orang dewasa, sebagai bentuk protes karena orang dewasa tidak memperhatikannya)"

Tante : "Iyo, piye-piye?"

Herman : : (menarik tangan tante, supaya tetap menonton TV dengan Herman)"

Selain itu perkembangan sensori motor ditunjukkan pula saat Herman mendapatkan pertanyaan dari tante, yakni:

Tante : "sandale ndi yo Herman?".

Herman : "(menginformasikan dengan cara menunjuk kearah sandal miliknya)".

Tante : "katoke ndi yo man?".

Herman : "(memegang celananya").

Tante : "bapak ndi man?".

Herman : "(menunjuk dengan jari telunjuk kearah bapaknya)”.

Pada kasus ini, anak penderita retardasi mental menggunakan kemampuan indra pendengar dengan gerak tangan yang ditujukan ke benda yang dimaksud. Perkembangan anak penderita retardasi mental memang mengalami keterlambatan pembentukan mental, namun anak retardasi mental dapat menanggapi atau merespon dengan baik terkait apa yang dikatakan atau disampaikan oleh orang dewasa. Hal tersebut tidak terlepas dari pembelajaran terus-menerus dan berulangulang yang dilakukan oleh orang tua dan keluarga yang berada di lingkungannya dan selalu mendukung serta menerimanya.

Peristiwa di atas membuktikan bahwa perkembangan sensomotor dan pemerolehan bahasa anak retardasi mental akan lebih cepat berkembang melalui adanya dukungan di lingkungan sekitar, hal ini sejalan dengan teori perkembangan behaviorisme yang menyampaikan bahwa adanya stimulus respon dalam proses pemerolehan bahasa akan meningkatkan perkembangan berbahasa pada anak penderita retardasi mental.

\section{Tahap Pemerolehan Bahasa Ibu Anak Penderita Retardasi Mental Usia 2 Tahun}

Kemampuan berbahasa merupakan suatu hal wajib yang harus dikuasai untuk memenuhi salah satu kebutuhan manusia sebagai makhluk sosial (Indah, 2017). Kemampuan pemerolehan bahasa harus dilakukan sejak dini, agar anak dapat mempelajari dan menguasai bahasa dengan baik sebagai salah satu alat komunikasi, belajar berinteraksi dan saling berhubungan, saling belajar dengan makhluk sosial lain. 
Hal tersebut dapat terlaksana dengan baik, apabila tahap-tahap yang diperlukan dapat terpenuhi. Tahap pemerolehan bahasa yang harus dilalui adalah tahap ocehan (babbling), tahap satu kata (holofrastic), tahap dua kata, dan tahap telegrafis. Tahap-tahap ini akan berkaitan dengan pemerolehan linguistik pada anak-anak yakni pemerolehan fonologi, pemerolehan sintaksis, dan pemerolehan semantik.

Indah (2017) menyampaikan bahwa dalam pemerolehan bahasa, seorang bayi yang baru lahir diperkirakan hanya memiliki sekitar 20\% dari kemampuan kapasitas otak orang dewasa. Oleh karena itu, bayi yang baru lahir hanya mampu menunjukkan kemampuan menangis serta menggerak-gerakkan anggota badannya. Bayi usia 3 hingga 4 bulan diperkirakan sudah mulai mengeluarkan bunyi. Mula-mula berupa tangisan, kemudian saat usia 6 bulan bayi mulai mengoceh. Selain itu, anak usia 6 bulan biasanya sudah mulai mengeluarkan bunyi-bunyi vokal atau konsonan. Kemampuan mengeluarkan bunyi-bunyi pada anak penderita retardasi mental mulai muncul pada usia 8 bulan. Proses pemerolehan bunyi dan bahasa ini ditunjukkan melalui beberapa tahapan-tahapan yang telah dilalui anak, seperti pada kasus ini adalah pemerolehan bunyi dan bahasa ibu pada Herman yang berusia 2 tahun yaitu sebagai berikut.

Pemerolehan bahasa pada anak penderita retardasi mental pada kasus Herman sudah melalui beberapa tahap diantaranya adalah tahap ocehan (babbling), tahap satu kata (holofrastic), tahap dua kata, dan tahap telegrafis. Tangisan atau suara berdekut bayi dianggap termasuk tahap pralinguistik atau praverbal karena suara tersebut hanya merupakan respon terhadap rangsangan di sekitarnya, bukan merupakan bentuk bentuk ujaran.

Tahap ocehan atau babbling merupakan peristiwa bahasa bagi anak yang akan bertambah variasi bahasanya, yakni anak dalam kondisi normal pada usia enam bulan sudah mulai mengoceh atau mengucapkan sejumlah bunyi-bunyi yang merupakan ujaran tanpa makna atau beberapa penggal kata yang bermakna karena ketidaksengajaan saja.

Pada kasus Herman, usia 4-6 bulan kondisinya belum dapat mengeluarkan bunyi-bunyi seperti dekutan atau pun ocehan, tetapi bunyi-bunyi atau dekutan muncul saat anak memasuki usia 8 bulan. Hal ini diketahui memalui kasus Herman yang pada usia 4-6 bulan baru menunjukkan perilaku menangis saja atau terdiam ketika mendapatkan stimulus bahasa yang dilakukan oleh orang tua, kemudian mengalami kemajuan yakni mampu merespon dengan menghasilkan bunyibunyi ketika memasuki usia 8 bulan. Bunyi yang dihasilkan merupakan hasil respon stimulus yang diberikan yakni muncul gabungan fonem vokal "aoao".

Pada tahap ocehan atau babbling ini, saat usia 8 bulan Herman belum mampu untuk menirukan pola intonasi yang diucapkan oleh orang-orang sekitar. Hal ini terjadi karena kemungkinan ada pengaruh gangguan penglihatan yang muncul pada kondisi anak, hal ini 
ditunjukkan melalui tidak dapatnya anak melihat dengan fokus orang yang mengajak berkomunikasi. Meskipun demikian, pada tahap ini, anak penderita retardasi mental sudah mampu menunjukkan kepekaan terhadap lingkungannya, melalui tindakan gerak kepala yang diayunkan untuk mengetahui suara yang muncul. Anak mulai mencari arah suara yang dihasilkan. Namun saat usia 10 bulan, Herman sudah mulai menunjukkan kemajuan melalui proses membabbling, yakni sudah mulai mampu menirukan intonasi dari orang-orang sekitar yang mengajak berkomunikasi serta secara perlahan menirukan bunyi-bunyi yang diucapkan oleh orang-orang di sekitar, contohnya ocehan " $a a$, $e h$ ”.

Tahap selanjutnya adalah tahap satu kata atau holofhrastic. Pada tahap ini, anak dalam kondisi normal usia satu tahun sudah mulai mampu menggunakan serangkaian bunyi berulangulang untuk makna yang sama. Biasanya anak mengucapkan kata "mam" untuk menyampaikan bahwa anak tersebut ingin meminta makan. Kata-kata dalam tahap ini memiiliki fungsi menghubungkan kata dengan perilaku anak, mengungkapkan perasaan, dan untuk memberi nama benda.

Pada kasus Herman, tahap holofrastic sudah mulai muncul, namun tahap ini muncul pada usia 1,7 tahun. Tahap holofrastic biasanya sudah mulai muncul pada anak usia 1 tahun, namun dalam kasus ini, tahap ini muncul pada usia 1,7 tahun atau hampir mencapai usia dua tahun. Hal ini terjadi karena pengaruh kemampuan fungsi otak yang tidak sempurna. Tahap holofrastic yang dihasilkan dan ditunjukkan anak retardasi mental yakni sudah mulai muncul tahap pelafalan satu suku kata yang mengandung bunyi vokal yakni bunyi vokal $a, u, o$, untuk menunjukkan respon terhadap rangsangan yang diberikan ketika proses berkomunikasi. Pelafalan yang ditunjukkan ini, sejalan dengan Indah (2017) yang menyampaikan bahwa kata-kata yang muncul pada tahap holofrastic biasanya terdiri dari fonem vokal dan konsonan yang mudah diucapkan, diantaranya $a, u, o$.

Tahap pelafalan satu kata yang ditunjukkan adalah kata $a a, b u, m m o h$, su. Pelafalan suku kata yang dihasilkan untuk menunjukkan beberapa hal, diantaranya, kata $b u$ digunakan Herman ketika ingin memanggil ibu, kata $a a$ digunakan ketika ingin memanggil bapak, kata mmoh yang berasal dari kata "emoh" atau tidak mau, digunakan ketika akan menolak sesuatu. Pada tahap holofrastik ini, belum banyak suku kata yang dihasilkan, hanya sekitar tiga atau emapat suku kata yang dihasilkan hingga usia dua tahun ini.

Tahap pemerolehan bahasa selanjutnya adalah tahap dua kata dan tahap telegrafis. Tahap dua kata adalah tahap anak mulai mengucapkan dua kata. Pada tahap ini, di usia dua tahun, Herman belum mampu untuk mengucapkan dua kata dalam jumlah banyak bahkan cenderung belum dapat 
mengucapkannya, hal ini disebabkan karena pada tahap holofrastic belum mampu menghasilkan bunyi-bunyi berupa suku kata bahasa secara masimal, baru beberapa saja yang dapat dihasilkan. Tahap dua kata ini yang muncul hanya "pak mam". Oleh karena itu, pada tahap ini belum dapat dilalui dengan baik pada kasus Herman.

Tahap selanjutnya adalah tahap telegrafis. Tahap telegrafis adalah tahap pemerolehan bahasa anak yang ditandai dengan pelafalan dua kata atau lebih untuk disusun menjadi sebuah kalimat. Pada tahap ini, belum dapat dihasilkan oleh Herman karena pada tahap sebelumnya atau tahap dua kata belum dapat dilalui dengan maksimal sehingga mempengaruhi tahap selanjutnya yakni tahap telegrafis.

\section{Tahap Pemerolehan Linguistik Anak Penderita Retardasi Mental Usia 2 Tahun}

Komponen pemerolehan bahasa anak, tanpa disadari sangat berkaitan dengan bagaimana kemampuan linguistik yang dimiliki oleh anak. Kemampuan Linguistik berkaitan pula dengan kecerdasan linguistik yang dimiliki oleh anak dalam memperoleh bahasanya. Komponen pemerolehan bahasa yang berkaitan dengan pemerolehan linguistik yang harus dilalui dan harus dikuasai diantaranya pemerolehan fonologi, pemerolehan sintaksis, dan pemerolehan semantik. Pemerolehan fonologi berkaitan dengan bunyi-bunyi yang dihasilkan oleh bayi-bayi pada tahap cooing, babbling, dan tahap pemerolehan bahasa murrni, sedangkan pemerolehan sintaksis dan semantik berkaitan dengan pemerolehan leksikon atau kosa kata serta pemaknaan dan pemahaman (Chaer, 2009). Ketiga komponen tata bahasa tersebut, tidak diperoleh secara bersaingan, melainkan diperoleh secara bersamaan. Menurut Chomsky dalam hipotesis Linguistik Generatif Transformasi, dalam kajian linguistik pemerolehan bahasa dimulai dari komponen semantik kemudian dilanjutkan dengan pemerolehan fonologi dan pemerolehan sintaksis.

Pada tahun pertama dalam kehidupannya, seorang bayi menghabiskan waktunya untuk mengamati dan mengumpulkan sebanyak-banyaknya informasi yang ada di sekitar kehidupannya. Pengamatan ini dilakukan melalui panca-indra yang dimiliki, terutama. Hasil dari pengamatan merupakan pengetahuan dunianya, dari hal inilah pemerolehan semantik diperoleh. Tahap pemerolehan semantik pada anak penderita retardasi mental ditunjukkan melalui tahapan pemaknaan ujaran yang didengar dan diajarkan oleh orang-orang di sekitarnya. Hal ini ditunjukkan melalui pemahan pada suatu hal atau barang yang berada di sekitar lingkungannya.

Herman saat usia 8 bulan, sudah mulai memperhatikan dan memahami mengenai hal-hal yang diajarkan di lingkungan sekitarnya, namun belum dapat fokus, baru pada usia 10 bulan Herman dapat melihat dan mendengar dengan lebih baik hal-hal yang diajarkan. Pengenalan dimulai melalui pengenalan hewan, tumbuhan, dan benda-benda lain yang sering dilihat. Melalui 
pemahaman ini, Herman mulai diajarkan kata-kata yang berkaitan dengan lingkungan aktivitasnya, misalkan hewan yang sering muncul adalah "cicak" yang mereka sebut "cecak", dan diucapkan Herman dengan [cak]. Herman memahami bahwa hewan berekor yang berada di atap adalah cicak, sehingga ketika melihat "tokek"Herman memahami bahwa hewan tersebut adalah cicak yang besar. Tumbuhan "rumput" yang disebut "suket" disebut Herman dengan [kst], diketahui Herman merupakan semua bentuk tumbuhan yang dapat diinjak dan berwarna hijau. Padahal belum tentu semua yang diinjak belum tentu berupa rumput, ada tumbuhan lain seperti "putri malu” yang dia sebut sebagai rumput. Meskipun demikian, ada beberapa hewan yang sudah bisa Herman bedakan yakni "belalang" dan "capung”.

Tahap pemerolehan semantik tersebut, sejalan dengan Teori Hipotesis Pemerolehan Semantik yang disampaikan Clark dalam Chaer (2009), yaitu pengalaman kanak-kanak mengenai dunia dan bahasa masih terbatas dibandingkan dengan orang dewasa, sehingga mengakibatkan kanak-kanak hanya akan menggunakan dua atau tiga fitur makna saja untuk sebuah kata sebagai masukan leksikon. Hal ini terjadi pada Herman yang menyebut "tokek" dengan nama "cicak". Pemerolehan semantik selanjutnya belum terlihat jelas, ketika orang tua menyebut "kursi" dan "meja", Herman sudah mulai memperhatikan, namun belum dapat menirukan. Pemerolehan semantik mempengaruhi bagaimana pemerolehan fonologi dan sintaksisnya, pada kasus Herman, pemerolehan semantik belum maksimal sehingga mempengaruhi pemerolehan fonologi dan sintaksisnya.

Tahap selanjutnya adalah tahap pemerolehan fonologi, berkaitan dengan kemampuan anak dalam mengucapkan bunyi-bunyi berupa kata yang sudah dipahami dan dikuasai. Pada tahap ini berkaitan pula dengan kemampuan anak ketika proses cooing atau dekutan serta babbling atau mencampurkan fonem konsonan dengan vokal. Seperti yang sudah disampaikan pada pembahasan sebelumnya, bunyi-bunyi yang dihasilkan oleh anak penderita retardasi mental muncul pada antara usia 8 bulan. Pada usia 6 bulan anak belum menghasilkan bunyi-bunyi, tetapi menunjukkan respon dengan gerakan kepala yang mencari suara-suara yang didengar. Bunyi dekutan yang dihasilkan berupa tangisan dan menghasilkan bunyi gabungan fonem vokal "aoao".

Tahap fonologi muncul pada usia antara 1,3 tahun hingga 1,7 tahun, bunyi yang dihasilkan sudah merupakan gabungan fonem vokal dan fonem konsonan. Pada pembahasan sebelumnya, tahap ini masuk ke dalam tahap pemunculan suku kata. Tahapan awal fonologi ditandai munculnya bunyi vokal yakni muncul kontras bunyi vokal lebar [a] dengan vokal [i], kemudian kontras vokal sempit [i] dengan vokal sempit belakang [u], kemudian baru muncul vonem vokal [e] dan vokal $[\mathrm{u}]$, serta vokal [o] dengan vokal [e]. Bunyi-bunyi tersebut mulai muncul saat proses babbling saat 
usia 10 bulan. Selanjutnya Herman mulai mengalami kemajuan meskipun suku kata yang dihasilkan belum banyak. Pada tahap pemerolehan fonologi, tidak hanya fonem vokal yang dihasilkan, tetapi sudah muncul fonem konsonan yakni fonem konsonan hambat bilabial [b], fonem konsonan nasal bilabial [m], serta konsonan frikatif [h] dan [s]. Bunyi konsonan tersebut berada pada tahap pemunculan satu suku kata, bunyi yang dihasilkan diantaranya $a a, b u, m m o h$, su. Bunyi "aa" untuk menyatakan sebutan bapak. Anak retardasi mental belum mampu menghasilkan bunyi "pak", tetapi terkadang mampu menghasilkan bunyi "ba". Ketika diajarkan kata "bapak" yang keluar adalah bunyi "aa". Sama halnya dengan bunyi "bu" untuk memanggil “ibu”, ketika diberikan arahan untuk menirukan bunyi ibu, anak menghasilkan bunyi "bu”. Pada bunyi "mmoh" yang berasal dari kata "emoh", ketika diberikan arahan untuk menirukan "emoh" bunyi yang dihasilkan "mmoh". Bunyi "su" yang berasal dari kata "susu", ketika diucapkan dengan tujuan memberikan arahan kepada anak supaya menirukan, bunyi yang dihasilkan adalah "su".

Tahap selanjutnya adalah tahap pemerolehan sintaksis. Pada kasus ini, tahap pemerolehan sintaksis muncul pada anak penderita retardasi mental kasus Herman saat berusia 2 tahun. Tahap sintaksis ditunjukkan melalui dua kata atau lebih yang dihasilkan anak penderita retardasi mental. Tahap pemerolehan sintaksis muncul ketika anak sudah mampu menghasilkan dan mengucapkan satu kata dengan jelas bahkan dua kata atau lebih. Pada kasus ini, Herman sudah mampu mengucapkan kata "ibu" dengan jelas saat berusia 2 tahun. Selain itu, muncul kata-kata baru seperti bobo, jajan, maem" namun belum maksimal. Pada tahap pemerolehan sintaksis, kata yang dihasilkan sudah merupakan kalimat meskipun tidak sesuai dengan kegramatikalan, tetapi sudah ditujukan untuk menginformasikan lebih banyak dari pada tuturannya. Misalkan Herman mengucapkan "pak, mam”, kata-kata ini muncul saat Herman ingin menginformasikan bahwa dia ingin meminta makan. Pada tahap sintaksis ini, Herman mampu mengucapkan bunyi hambat bilabial [p].

Pada tahap sintaksis ini, belum banyak kata yang mampu dihasilkan dan diucapkan oleh Herman. Hal ini disebabkan karena, saat tahap fonologi yakni tahap holofrastic, kata yang dihasilkan belum banyak dan masih membutuhkan proses, sehingga mempengaruhi proses pemerolehan sintaksisnya.

Dari pembahasan di atas, hasil pemerolehan bahasa pada tahap holofrastic dapat dilihat pada tabel berikut. 
Tabel 3. Pemerolehan Bahasa pada Tahap Holofrastic

\begin{tabular}{cc}
\hline Ujaran & Pelafalan \\
\hline Bapak & {$[\mathrm{a}$ ?] } \\
Ibu & {$[\mathrm{b} \mathrm{u}]$} \\
Susu & {$[\mathrm{s} \mathrm{u}]$} \\
Emoh & {$[\mathrm{mm} \mathrm{o} \mathrm{h}]$} \\
Cecak & {$[\mathrm{c} \mathrm{a} \mathrm{k}]$} \\
Suket & {$[\mathrm{o}]$} \\
Maem & {$[\mathrm{m} \mathrm{a} \mathrm{m}]$} \\
Bobo & {$[\mathrm{b} \mathrm{u}]$} \\
Jajan & {$[\mathrm{a} \mathrm{n}]$} \\
\hline
\end{tabular}

Tahap dua kata yang dihasilkan baru sebatas "pak, mam", dan belum ditemukan kata-kata lain. Tahap pemerolehan sintaksis yang dihasilkan Herman, berkaitan dengan teori Tata Bahasa Nurani yang di dalamnya behubungan pula dengan tata bahasa generatif transformasi yang dikemukakan Chomsky. Teori ini sangat berpengaruh dalam pemerolehan dan perkembangan bahasa secara sintaksis pada kanak-kanak. Pengetahuan kanak-kanak mengenai hubunganhubungan tata bahasa ini bersifat "nurani", oleh karena itu, tahap dua kata yang dihasilkan Herman, yakni "pak, mam" memiliki rumus "subject-of" (K $\rightarrow$ FN + FV). Chomsky menyampaikan K merupakan kalimat, FN merupakan frasa nomina, dan FN merupakan frase verbal. Tahap dua kata milik Herman yakni "pak, mam" memiliki hubungan dan struktur yang dapat diuraikan sebagai berikut:

“pak, mam” $\rightarrow$ (Herman menyatakan bapak sedang makan)

"pak, mam” $\rightarrow$ (Herman meminta makan pada bapak)

Pemerolehan dua kata yang diperoleh Herman, menginformasikan sesuatu hal yang berbeda dilihat dari tujuan atau situasi dari kata tersebut, hal ini sama seperti yang disampaikan oleh Bloom yang menyampaikan bahwa kata-kata yang dihasilkan anak-anak merujuk pada informasi situasi tertentu. Dengan demikian, dapat disampaikan bahwa pemerolehan bahasa dua kata pada kasus Herman berjalan sesuai dengan struktur yang ada, meskipun masih sangat minim sekali kata-kata yang dihasilkan. Hal ini dikarenakan orang tua jarang mengajak berkomunikasi ketika sedang bersama. Hal ini disebabkan karena, pihak ibu dari Herman bekerja, sedangkan ayah dari Herman ketika bersama jarang mengajak untuk berkomunikasi. Herman lebih banyak menghabiskan waktu bersama dengan ayah dari pada ibunya, oleh karenanya perlu menjadi bahan pertimbangan terkait pendekatan orang sekitar untuk memberikan stimulus kebahasaan sebagai penunjang pemerolehan bahasa. 


\section{SIMPULAN}

Berdasarkan kajian yang telah dilakukan dengan objek anak penderita retardasi mental berusia 2 tahun, maka dapat disimpulkan bahwa tahapan-tahapan pemerolehan Bahasa terdiri dari beberapa tahapan, yakni: tahap pemerolehan kognitif, tahap pemerolehan bahasa ibu, dan tahap pemerolehan linguistic. Tahapan-tahapan tersebut dapat berjalan dan dapat dilalui oleh anak penderita retardasi mental meskipun mengalami keterlambatan. Keterlambatan pemerolehan bahasa anak retardasi mental dipengaruhi oleh perkembangan otak dan juga kurangnya stimulus bahasa yang diberikan dari lingkungan. Anak penderita retardasi mental memiliki permasalahan yang kompleks baik kemampuan kognitif maupun kemampuan motoriknya.

Meskipun demikian, anak penderita retardasi mental mempunyai perkembangan kognitif yang cukup baik bila dilatih secara terus-menerus dan perkembangannya dikontrol oleh orang tua dan orang-orang yang berada di sekitarnya. Pemberian stimulus bahasa secara terus-menerus dan berkelanjutan perlu dilakukan untuk menunjang pemerolehan bahasa ibu pada anak penderita retardasi mental. Hal ini dilakukan untuk meningkatkan pemahaman dan meningkatkan pemerolehan kosa kata bahasa ibu pada anak penderita retardasi mental.

\section{DAFTAR PUSTAKA}

Alwisol. (2009). Psikologi Kepribadian. Malang: UMM Press.

Arsanti, M. (2014). Pemerolehan Bahasa pada Anak (Kajian Psikolinguistik). Jurnal PBSI, 3 (2), 24-47.

Chaer, A. (2009). Psikolinguistik. Jakarta: Rieneka Cipta.

Dardjowidjojo, S. (2008). Psikolinguistik (Pengantar Pemahaman Bahasa Manusia). Jakarta: Yayasan Obor Indonesia.

Endarwati, O. (2015). Cacat Sintaksis Keluaran Wicara Pada Anak Penyandang Autis di SD Lab PGSD Setia Budi dan SDIT Al-Mubarak Rawasari (Suatu Kajian Neurolinguistik). Jurnal Atkhais, 6 (1).

Martina, S. C., \& Saman, S. (2014). Ativitas Berbahasa Anak Berkebutuhan Khusus pada Lembaga Pendidikan dan Pelatihan Bina Anak Bangsa Kota Pontianak. Jurnal Pendidikan dan Pembelajaran Khatulistiwa, 3 (10), 1-14.

Indah, R. N. (2017). Gangguan Berbahasa. Malang: UIN-MALIKI Press.

Leech, G. N. (1983). Principles of Pragmatics. London: Longman.

Putri A. K., Mawarni H., Yara N. Y., \& Sumarlam. (2018). Kemampuan Berbahasa Anak Lahir Prematur Usia Dua Tahun: Kajian Psikolinguistik. Jurnal Arkhais, 9 (1), 139-146.

Pandudinata R., Sumarlam, S., \& Saddhono K. (2018). Pemerolehan Bahasa Siswa Tunagrahita Kelas VI SD. Jurnal Retorika, 11, 48-56. 
Pratiwi, I. C., Handayani, O. W. K., \& Raharjo, B. B. (2017). Kemampuan Kognitif Anak Retardasi Mental Berdasarkan Status Gizi. Public Health Perspective Journal, 2 (1), 19-25.

Ramayumi, R., Nurdin, A. E., \& Nurhajjah, S. (2014). Karakteristik Penderita Retardasi Mental di SLB Kota Bukittinggi. Jurnal Majalah Kedokteran Andalas, 37 (3), 181-186.

Steinberg, D. D., \& Sciarini, N. V. (2006). An Introduction to Psycholinguitics. Great Britain: Pearson Longman.

Soetjiningsih. (2014). Tumbuh Kembang Anak. Jakarta: EGC.

Tarigan, H. G. (2009). Psikolinguistik. Bandung: CV. Angkasa. 